IOSR Journal of Pharmacy

e-ISSN: 2250-3013, p-ISSN: 2319-4219, www.iosrphr.org

Volume 2 Issue 6 || || Nov-Dec. 2012 || || PP.33-42

\title{
Effects of Potassium and Magnesium on Some Hemodynamic and Renal Function Related Parameters in 2k1c Hypertensive Rats
}

\author{
${ }^{1}$ Hawzheen Karem Othman, ${ }^{2}$ Almas M. R. Mahmud \\ Dept.of Biology, College of Science, University of Salahaddin, Erbil. Kurdistan, Iraq
}

\begin{abstract}
The present study was done to investigate the effect of potassium and magnesium on aldosterone level, systolic blood pressure (SBP), heart rate (HR); renal function test parameters, serum nitric oxide (NO) and malondialdehyde (MDA) in 2-kidney, 1-clip (2K1C) hypertensive rats. The experimental rats were divided into six groups, each with seven rats and the treatments were continued for 4 weeks: Group 1: Control, Group 2: Sham operated surgery rats, Group 3: $2 \mathrm{KlC}$ hypertensive rats, Group4: $2 \mathrm{KIC}+$ Potassium chloride, $\mathrm{KCl}$ (80 gms/Kg diet) , Group5: $2 \mathrm{KlC}+$ Magnesium sulphate ,MgSO4 (80 gms/Kg diet), Group6: $2 \mathrm{K1C}$ $+\mathrm{KCl}+\mathrm{MgSO} 4(160 \mathrm{gms} / \mathrm{Kg}$ diet). The results showed that renal artery constriction caused significant elevation in SBP and HR. Furthermore, serum levels of aldosterone, serum MDA, sodium ions $\left(\mathrm{Na}^{+}\right)$, chloride ions ( $\mathrm{Cl}$ ), creatinine and urine $\mathrm{Na}^{+}$levels were also elevated significantly in $2 \mathrm{K1C}$ hypertensive rats. On the other hand, administration of potassium decreased significantly SBP,HR, serum level of aldosterone, MDA, serum $\mathrm{Na}^{+}$and creatinine, while, serum levels of $\mathrm{NO}, \mathrm{K}^{+}$and glomerular filtration rate $(\mathrm{GFR})$ significantly increased compared with values in 2 K1C hypertensive rats. Magnesium supplementation in 2 KIC hypertensive rats caused significant decrease in $\mathrm{SBP}, \mathrm{HR}$, serum aldosterone level, serum $\mathrm{MDA}, \mathrm{Cl}$, calcium ions $\left(\mathrm{Ca}^{2+}\right)$ and increased serum levels of $\mathrm{NO}$ and magnesium ions $\left(\mathrm{Mg}^{2+}\right)$ levels compared with $2 \mathrm{~K} 1 \mathrm{C}$ hypertensive group. Moreover, administration of potassium in combination with magnesium in $2 \mathrm{KIC}$ hypertensive rats caused significant decrease in $\mathrm{SBP}$, serum aldosterone level, $\mathrm{HR}$, serum $\mathrm{MDA}, \mathrm{Na}{ }^{+}, \mathrm{Cl}, \mathrm{Ca}^{2+}$, creatinine and serum levels of $\mathrm{NO}, \mathrm{K}^{+}, \mathrm{Mg}^{2+}$ and GFR were increased significantly, while, no significant change recorded in urine $\mathrm{Na}^{+}$levels compared all values with $2 \mathrm{~K} 1 \mathrm{C}$ hypertensive rats. Conclusion: The blood pressure lowering characteristic of potassium and magnesium was attributed to increase serum NO levels. The reduced serum MDA levels in hypertensive rats suggest that potassium and magnesium have antioxidant properties by reducing oxidative stress and preventing lipid peroxidation.
\end{abstract}

Keywords-Potassium, Magnesium, Two-Kidney One-Clip hypertensive rats, Renin-angiotensin system, Nitric oxide.

\section{INTRODUCTION}

Hypertension is one of the most important risk factors for cardiovascular disease, atherosclerosis, coronary artery disease, cerebrovascular accidents, heart and renal failure and it is the leading cause of death worldwide (61). Studies show that the renin-angiotensin-aldosterone system (RAAS) is responsible for the regulation of systemic blood pressure, as well as, salt and water homeostasis and the maintenance of vascular tone (66). In the RAAS, renin, generated in the juxtaglomerular apparatus of the kidney, catalyzes the conversion of angiotensinogen to angiotensin I (Ang I). Then, angiotensin converting enzyme (ACE), converts the inactive decapeptide angiotensin I (Ang I) to the octapeptide angiotensin II (Ang II). Ang II stimulates the production of aldosterone, a mineralocorticoid that exerts sodium and water retaining effects on the distal tubule (8).

The well known model for generating hypertension dependent Ang II secretion is 2K1C Goldblatt model. (47), through it one renal artery chronically constricted by clip process and the other one untouched to reduce renal perfusion (49). After reduction in renal perfusion pressure renin synthesis and release increases from the juxtaglomerular cells and some time from the principal cells of collecting tubules, cortical and medullary collecting ducts of renal constricted kidney (51). (38),

It was found that after 4 weeks of renal artery stenosis in rats, the increased Ang II releases aldosterone from adrenal cortex leading to salt and water retention(38). Also Ang II increases the activity of the sympathetic nervous system stimulates vasopressin secretion, and enhances $\mathrm{NaCl}$ reabsorption in the kidney (41). while, in non-clipped kidney progressive elevations in arterial pressure causes renin depletion the phenomenon of pressure natriuresis (10)

Potassium ion has low concentration in the extracellular fluid compare with intracellular fluid. Therefore increase dietary $\mathrm{K}$ has benefits in the treatment of hypertension, arrhythmia, decrease renal vascular damage and inhibiting oxygen free radical formation from vascular endothelial cells (7). 
Effects of potassium and magnesium on some hemodynamic and renal function related...

The second high intracellular ion and the the fourth abundant cation in the body is magnesium (6). It has many functions in the body. Magnesium attenuates generation of reactive oxygen species (ROS) and stimulates production of prostacyclins and NO that have vasodilatation properties (60). The present study was done to investigate the effect of potassium and magnesium on aldosterone level, SBP, HR; renal function test parameters, serum NO and MDA in $2 \mathrm{~K} 1 \mathrm{C}$ hypertensive rats

\section{MATERIALS AND METHODS}

\section{A-Animals and housing}

Forty two adult male albino rats of about (150-250gms) body weight and (6-8) weeks old were used in the present study. Animals were housed in plastic cages bedded with wooden chips. They were housed under standard laboratory conditions, 12:12 light/dark photoperiod at $22 \pm 2 \mathrm{C}^{0}$. The animals were given standard rat pellets and tap water ad libitum

\section{B-Experimental design}

This experiment was designed to study the effects of $\mathrm{KCl}, \mathrm{MgSO}_{4}$ and their combination on some hemodynamic and renal function test parameters in 2-kidney 1-clip (Goldblatt) hypertensive rats. The experimental rats were divided into six groups, each with seven rats and the treatments were continued for 4 weeks

Group 1: Control

Group 2: Sham operated surgery rats

Group 3: $2 \mathrm{~K} 1 \mathrm{C}$ hypertensive rats

Group4: $2 \mathrm{~K} 1 \mathrm{C}+\mathrm{KCl}(80 \mathrm{gms} / \mathrm{Kg}$ diet $)$

Group5: $2 \mathrm{~K} 1 \mathrm{C}+\mathrm{MgSO}_{4}(80 \mathrm{gms} / \mathrm{Kg}$ diet $)$

Group6: $2 \mathrm{~K} 1 \mathrm{C}+\mathrm{KCl}+\mathrm{MgSO}_{4}(160 \mathrm{gms} / \mathrm{Kg}$ diet $)$.

\section{C-Clipping procedure}

The left renal artery was detached from male albino rats under anesthesia with combination of ketamine hydrochloride and xylazine intra-peritoneally in a dose of $35 \mathrm{mg} / \mathrm{kg}$ and $5 \mathrm{mg} / \mathrm{kg}$ body weight, respectively, (Laird et al., 1996)and a silver clip of a $0.25 \mathrm{~mm}$ width was placed on the artery for inducing stenosis in the renal artery, to make hypertensive rats (2K1 clip rats)(37).

\section{Collection of blood samples}

At the end of the experiment, the rats were anesthetized with ketamine hydrochloride $(50 \mathrm{mg} / \mathrm{kg})$. Blood samples were taken by cardiac puncture into chilled tubes and centrifuged at $3000 \mathrm{rpm}$ for 20 minutes; then sera were stored at $-85 C^{0}$ until assay.

\section{E-Collection of urine samples.}

On the $30^{\text {th }}$ day of experiments, 24-h urine samples were collected from all rats. After volume measurements, the samples were stored at $-80 \mathrm{C}^{0}$ (Sanyo, Japan) until assay.

\section{F. Blood pressure and heart rate measurements}

Measurements of SBP and HR were obtained at the end of experiment by the tail-cuff method in all groups using NIBP controller system 125 ML.R connected to power Lab (AD Instruments, power lab 2/25). Rats were placed in a restraining chamber and warmed to an ambient temperature of approximately $37 \mathrm{C}^{0}$, typically taking about 10-15 minutes, after that occluding cuffs and pneumatic pulse transducers were placed on the rats' tails. Six readings were taken for each rat, the highest, lowest and any associated with excess noise or animal movement were discarded. The average was taken of the remaining readings to generate a value for a given rat for that week.

\section{G. Biochemical determination 1.Determination of serum malonaldehyde (MDA)}

The level of serum MDA was determined spectrophotometrically with a thiobarbituric acid (TBA) solution. In brief to $150 \mu \mathrm{l}$ serum sample added the followings: $1 \mathrm{ml}$ trichloroacetic acid (TCA) $17.5 \%, 1 \mathrm{ml}$ of 0.66 $\%$ TBA, mixed well by vortex, incubated in boiling water for 15 minutes, and then allowed to cool. Then add $1 \mathrm{ml}$ of $70 \% \mathrm{TCA}$, and let the mixture to stand at room temperature for 20 minutes, centrifuged at $2000 \mathrm{rpm}$ for 15 minutes, \& take out the supernatant for scanning spectrophotometrically. The concentration of MDA was calculated as follow:

MDA $(\mu \mathrm{mol} / \mathrm{L})=$ Absorbance at $532 \mathrm{~nm} \times \mathrm{D} / \mathrm{L} \times$ Eo

Where L: light bath $(1 \mathrm{~cm})$

Eo: Extinction coefficient 1.56 x $105 \mathrm{M}-1 . \mathrm{Cm}-1$

D: Dilution factor $=1 \mathrm{ml} \mathrm{Vol}$. used in ref. $/ 0.15=6.7$ 
Effects of potassium and magnesium on some hemodynamic and renal function related...

\section{2-Determination of serum aldosterone $(\mathrm{pg} / \mathrm{ml})$ by Enzyme linked immunosorbent assay (ELISA) kit for rat aldosterone}

Serum aldosteron level was measured using the ELISA kit which is a sandwich enzyme immunoassay for the in vitro quantitative measurement of rat aldosteone in serum, plasma and other biological fluids.

3- Serum total nitric oxide measurement

Serum total NO was determined by NO non-enzymatic assay kit (US Biological, USA).

\section{H-Assay of electrolytes}

1-Determination of serum and urine electrolytes

Serum levels of $\mathrm{Na}^{+}, \mathrm{K}^{+}$and $\mathrm{Cl}^{-}$and urine level of $\mathrm{Na}^{+}$were determined by electrolyte analyzer (EIITE), electra biomedical corporation (USA).

\section{2-Determination of serum magnesium} France).

Magnesium level in serum and urine was determined by spectrophotometer magnesium kit(Biolab,

\section{3-Determination of serum total calcium}

Spectrophotometric method was used for serum calcium determination. In alkaline solution, CPC (OCresol Phtalein Compleone) reacts with calcium to form a dark-red colored complex(Biolab, France).

\section{I-Determination of serum and urine creatinine}

Serum and urine creatinine level was determined by spectrophotometer creatinine kit(Biolab, France).

\section{J-Glomerular filtration rate (GFR) determination:}

Glomerular filtration rate was determined by measuring the renal clearance of endogenous creatinine. During experiments, blood and urine samples were taken as described previously. Chemical analysis of diluted urine and blood samples for creatinine was performed using the methods quoted by (65). The GFR was calculated as follow: $\mathrm{GFR}=\mathrm{U} * \mathrm{~V} / \mathrm{P}(17)$

Where,

$\mathbf{U}$ and $\mathbf{P}=$ the concentration of the creatinine in urine and plasma respectively. $\mathbf{V}=$ the rate of urine flow in $\mathrm{ml} / \mathrm{min}$

\section{STATISTICAL ANALYSIS}

Analysis of data was performed by using \{statistical package for social science (SPSS) version 11.5\}. Results are expressed as mean \pm standard error (mean $\pm \mathrm{SE})$. Statistical differences were determined by Ducan's test for multiple comparisons after analysis of variance (ANOVA)(14).

\section{RESULTS}

The SBP of 2K1C Goldblatt hypertensive rats increased significantly $(\mathrm{p}<0.01)$ and reached $(149.1 \pm 3.52$ $\mathrm{mmHg})$ after 4 weeks of operation as compared with control $(111.5 \pm 0.56 \mathrm{mmHg})$. On the other hand, SBP decreased significantly $(\mathrm{p}<0.01)$ in $2 \mathrm{~K} 1 \mathrm{C}$ animals that were provided with diet supplemented with $\mathrm{KCl}, \mathrm{MgSO}_{4}$ and their combination $(115.5 \pm 0.36 \mathrm{mmHg}),(110.5 \pm 0.42 \mathrm{mmHg})$ and $(107.3 \pm 0.42 \mathrm{mmHg})$, respectively, compared with $2 \mathrm{~K} 1 \mathrm{C}$ hypertensive rats (Table 1). The $2 \mathrm{~K} 1 \mathrm{C}$ hypertensive rats showed a significant $(\mathrm{P}<0.01)$ increase in HR (471.1 \pm 4.9 beats $/ \mathrm{min})$ when compared with control $(341.1 \pm 6.7$ beats $/ \mathrm{min})$, while, a significant ( $\mathrm{p}<0.01)$ reduction occurred in $\mathrm{HR}$ of $2 \mathrm{~K} 1 \mathrm{C}$ hypertensive rats treated with $\mathrm{KCl}, \mathrm{MgSO}_{4}$ and their combination (397.6 \pm 3.4 beats $/ \mathrm{min}),(406.8 \pm 1.7$ beats $/ \mathrm{min})$ and $(395.1 \pm 4.1$ beats $/ \mathrm{min})$ respectively, in comparison with 2K1C hypertensive rats (Table 1 ).

Statistical analysis revealed non significant changes in serum total NO level in $2 \mathrm{~K} 1 \mathrm{C}$ hypertensive rats compared with control group. On the other hand, $2 \mathrm{~K} 1 \mathrm{C}$ hypertensive rats treated with $\left(\mathrm{KCl}, \mathrm{MgSO}_{4}\right.$ and their combination) showed significant $(\mathrm{p}<0.05)$ increases in serum total NO levels $(9.27 \pm 0.13 \mu \mathrm{mol} / \mathrm{L}),(9.43 \pm 0.28$ $\mu \mathrm{mol} / \mathrm{L})$ and $(9.00 \pm 0.23 \mu \mathrm{mol} / \mathrm{L})$, respectively, compared to $2 \mathrm{~K} 1 \mathrm{C}$ hypertensive $(8.22 \pm 0.11 \mu \mathrm{mol} / \mathrm{L}) \mathrm{group}$ (Table 1). Serum aldosterone level in $2 \mathrm{~K} 1 \mathrm{C}$ hypertensive rats increased $(59.61 \pm 10.0 \mathrm{pg} / \mathrm{ml})$ significantly $(\mathrm{p}<0.05)$ as compared with control $(12.96 \pm 1.05 \mathrm{pg} / \mathrm{ml})$ group. On the other hand, supplementation of $\mathrm{KCl}$, $\mathrm{MgSO}_{4}$ and their combination in $2 \mathrm{~K} 1 \mathrm{C}$ hypertensive rats prevented the rise in serum aldosterone level significantly $(\mathrm{p}<0.05)(7.8 \pm 2.0 \mathrm{pg} / \mathrm{ml}),(14.52 \pm 1.18 \mathrm{pg} / \mathrm{ml})$ and $(14.56 \pm 2.13 \mathrm{pg} / \mathrm{ml})$, respectively, in comparison with $2 \mathrm{~K} 1 \mathrm{C}$ hypertensive rats (Table 1 ).

The level of MDA was increased significantly $(\mathrm{P}<0.05)$ in $2 \mathrm{~K} 1 \mathrm{C}$ hypertensive group $(5.57 \pm 0.23$ $\mu \mathrm{mol} / \mathrm{L})$ compared with control $(2.09 \pm 0.04 \mu \mathrm{mol} / \mathrm{L})$ group, while, a significant $(\mathrm{P}<0.05)$ reduction occurred in MDA level $(3.11 \pm 0.06 \mu \mathrm{mol} / \mathrm{L})$ in $2 \mathrm{~K} 1 \mathrm{C}$ hypertensive rats supplied with $\mathrm{KCl}$. However, a greater reduction in 
serum MDA levels recorded in rats supplied with $\mathrm{MgSO}_{4}$ and combination of $\left(\mathrm{KCl}\right.$ and $\left.\mathrm{MgSO}_{4}\right)(2.5 \pm 0.10$ $\mu \mathrm{mol} / \mathrm{L})$ and $(2.42 \pm 0.15 \mu \mathrm{mol} / \mathrm{L})$, respectively, compared all with $2 \mathrm{~K} 1 \mathrm{C}$ hypertensive rats (Table 1$)$.

Serum $\mathrm{Na}^{+}$concentration of the $2 \mathrm{~K} 1 \mathrm{C}$ hypertensive group $(129.33 \pm 1.76 \mathrm{mmol} / \mathrm{L})$ was significantly higher $(P<0.05)$ than that of the control $(127.85 \pm 1.14 \mathrm{mmol} / \mathrm{L})$ group. In $2 \mathrm{~K} 1 \mathrm{C}$ hypertensive rats along with $\mathrm{KCl}$ treatment had significantly $(\mathrm{p}<0.05)$ decreased serum $\mathrm{Na}^{+}$concentration $(123.05 \pm 1.7 \mathrm{mmol} / \mathrm{L})$, whereas, $\mathrm{MgSO}_{4}$ treatment did not change serum $\mathrm{Na}^{+}$concentration, co-administration of $\mathrm{KCl}$ along with $\mathrm{MgSO}_{4}$ significantly $(\mathrm{P}<0.05)$ decreased serum $\mathrm{Na}^{+}$concentration $(124.6 \pm 1.2 \mathrm{mmol} / \mathrm{L})$ compared all with $2 \mathrm{~K} 1 \mathrm{C}$ hypertensive rats (Table1).

Two- kidney, one-clipped hypertensive rats showed non significant change in serum $\mathrm{K}^{+}$concentration in compared with control group. On the other hand, treatment by $\mathrm{KCl}$ alone and in combination with $\mathrm{MgSO}_{4}$ in $2 \mathrm{~K} 1 \mathrm{C}$ hypertensive rats caused significant increase $(\mathrm{p}<0.01)$ in serum $\mathrm{K}^{+}$concentration $(5.11 \pm 0.10 \mathrm{mmol} / \mathrm{L})$ and $(5.30 \pm 0.18 \mathrm{mmol} / \mathrm{L})$, respectively, whereas, rats treated with $\mathrm{MgSO}_{4}$ showed no significant differences in serum $\mathrm{K}^{+}$concentration compared all with $2 \mathrm{~K} 1 \mathrm{C}$ hypertensive rats, $(3.82 \pm 0.15 \mathrm{mmol} / \mathrm{L})($ Table 2$)$.

Serum $\mathrm{Cl}^{-}$level was increased significantly $(\mathrm{P}<0.05)$ in $2 \mathrm{~K} 1 \mathrm{C}$ hypertensive rats $(115.4 \pm 0.5 \mu \mathrm{mol} / \mathrm{L})$ compared with control $(104.6 \pm 0.7 \mathrm{mmol} / \mathrm{L})$ group. Moreover, in $2 \mathrm{~K} 1 \mathrm{C}$ hypertensive rats $\mathrm{KCl}$ caused non significant change in serum $\mathrm{Cl}^{-}$level, however, a significant decrease in serum $\mathrm{Cl}^{-}$levels recorded in rats supplied with $\mathrm{MgSO}_{4}$, and combination of $\left(\mathrm{KCl}\right.$ and $\left.\mathrm{MgSO}_{4}\right)(108.6 \pm 0.21 \mathrm{mmol} / \mathrm{L})$ and $(109.6 \pm 0.7 \mathrm{mmol} / \mathrm{L})$, respectively, compared all with $2 \mathrm{~K} 1 \mathrm{C}$ hypertensive rats (Table 2). No significant differences in serum $\mathrm{Mg}^{2+}$ levels were recorded among $2 \mathrm{~K} 1 \mathrm{C}$, control group.

Also, in $2 \mathrm{~K} 1 \mathrm{C}$ rats $\mathrm{KCl}$ treatment caused non significant change in serum $\mathrm{Mg}^{2+}$ level, whereas, $\mathrm{MgSO}_{4}$ alone and in combination with $\mathrm{KCl}$ significantly increased $(\mathrm{p}<0.01)$ serum $\mathrm{Mg}^{2+}$ level $(2.11 \pm 0.06 \mathrm{mg} / \mathrm{dL})$ and $(2.16 \pm 0.06 \mathrm{mg} / \mathrm{dL})$, respectively, compared with $2 \mathrm{~K} 1 \mathrm{C}$ hypertensive rats $(1.38 \pm 0.14 \mathrm{mg} / \mathrm{dL})($ Table 2$)$.

Two kidney one clip hypertensive rats showed non significant change in serum total $\mathrm{Ca}^{2+}$ when compared with control group. Potassium chloride treatments in $2 \mathrm{~K} 1 \mathrm{C}$ hypertensive rats caused non significant change in serum total $\mathrm{Ca}^{2+}$, while, $\mathrm{MgSO}_{4}$ alone and in combination with $\mathrm{KCl}$ decreased serum total $\mathrm{Ca}^{2+}$ significantly $(\mathrm{p}<0.05)(7.07 \pm 0.17 \mathrm{mg} / \mathrm{dL})$ and $(7.16 \pm 0.19 \mathrm{mg} / \mathrm{dL})$, respectively, compared all with $2 \mathrm{~K} 1 \mathrm{C}$ hypertensive rats $(9.39 \pm 0.08 \mathrm{mg} / \mathrm{dL})($ Table 2$)$.

Concentration of urine $\mathrm{Na}^{+}$significantly increased $(\mathrm{p}<0.05)$ in $2 \mathrm{~K} 1 \mathrm{C}$ hypertensive rats $(206.66 \pm 1.33$ $\mathrm{mmol} / \mathrm{L})$ compared to control $(199.71 \pm 0.99 \mathrm{mmol} / \mathrm{L})$ group, respectively. Moreover, a significant increase $(\mathrm{p}<0.05)$ in $\mathrm{Na}^{+}$concentration was recorded in $2 \mathrm{~K} 1 \mathrm{C}$ hypertensive rats treated with $\mathrm{KCl}$ in diet $(212.00 \pm 0.81$ $\mathrm{mmol} / \mathrm{L})$, while, $\mathrm{MgSO}_{4}$ and combination of $\left(\mathrm{KCl}\right.$ and $\left.\mathrm{MgSO}_{4}\right)$ treatment caused non significant changes in urine $\mathrm{Na}^{+}$concentrations compared with $2 \mathrm{~K} 1 \mathrm{C}$ hypertensive rats (Table 2).

A significant increase $(\mathrm{p}<0.05)$ in serum creatinine level was recorded in

$2 \mathrm{~K} 1 \mathrm{C}$ hypertensive rats $(2.661 \pm 0.12 \mathrm{mg} / \mathrm{dL})$ when compared to control $(0.953 \pm 0.03 \mathrm{mg} / \mathrm{dL})$, group, while, serum creatinine level significantly decreased in $2 \mathrm{~K} 1 \mathrm{C}$ hypertensive rats treated with $\mathrm{KCl}$ and combination of $\mathrm{KCl}$ and $\mathrm{MgSO}_{4}(1.15 \pm 0.03 \mathrm{mg} / \mathrm{dL}),(0.7 \pm 0.16 \mathrm{mg} / \mathrm{dL})$ when compared with $2 \mathrm{~K} 1 \mathrm{C}$ hypertensive rats. On the other hand, $\mathrm{MgSO}_{4}$ caused non significant changes in serum creatinine level when compared with $2 \mathrm{~K} 1 \mathrm{C}$ hypertensive rats (Figure 1).

Renal artery constriction in 2K1C hypertensive rats had non significant effect on GFR when compared with control group, while, GFR was increased significantly $(\mathrm{P}<0.01)$ in $2 \mathrm{~K} 1 \mathrm{C}$ hypertensive rats that were treated with $\mathrm{KCl}$ and combination of $\left(\mathrm{KCl}\right.$ and $\left.\mathrm{MgSO}_{4}\right)$ with mean values $(2.27 \pm 1.13 \mathrm{ml} / \mathrm{min})$ and $(2.57 \pm 0.12 \mathrm{ml} / \mathrm{min})$, respectively. Moreover, $\mathrm{MgSO}_{4}$ had no significant effect compared with $2 \mathrm{~K} 1 \mathrm{C}$ hypertensive group $(1.52 \pm 0.05$ $\mathrm{ml} / \mathrm{min}$ ) (Figure 2).

\section{DISCUSSION}

The renal artery constriction in 2K1C rats caused marked increase in SBP. Previous studies showed that unilateral renal artery stenosis in $2 \mathrm{~K} 1 \mathrm{C}$ rat can lead to hypertension, returninig this to the renal atrophy, and reduced renal function $(43 ; 49)$. A reduced renal perfusion pressure after clipping of arenal artery in the early (2-to 4 week) 2K1C rat model of Goldblatt hypertension increases Ang II concentrations in both kidneys and causes Ang II- dependent hypertension(44)

The present results show that renal artery constriction for four weeks caused an increase in plasma aldosterone concentration, suggesting that aldosterone could play a pathophysiological role in $2 \mathrm{~K} 1 \mathrm{C}$ hypertension subsequent to activation of the RAAS and as demonstrated by (5), renal artery occlusion creates ischemia, which triggers the release of renin. Hyperreninemia promotes production of Ang II, causing severe vasoconstriction and release of aldosterone.

Our results also show that experimentally induced-hypertension in $2 \mathrm{~K} 1 \mathrm{C}$ rats produced a significant increase in HR. The mechanism by which $2 \mathrm{~K} 1 \mathrm{C}$ rats showed an increase in HR may be due to interactions between RAS and sympathetic nervous system since it has been well recognized that strong sympathetic stimulation can increase the HR (57). Moreover, a role for changes in sympathetic nervous system in 2K1C 
hypertension has been suggested. (34) reported that sympathetic tone is inappropriately increased and this sympathetic tone ameliorates hypertension and HR in Goldblatt animals. However, involvement of oxidative stress in early $2 \mathrm{~K} 1 \mathrm{C}$ Goldblatt hypertensive rats has been demonstrated by prolonged administration of Tempol (free radical scavenger) to reduce ROS (44).

The present results show that potassium treatment attenuated the development of hypertension and also led to decrease of existing hypertension in $2 \mathrm{~K} 1 \mathrm{C}$ Goldblatt hypertensive rats. The antihypertensive effect of $\mathrm{K}^{+}$ was accompanied by suppression of plasma aldosterone activity. Different potential mechanistic pathways may explain how increasing $\mathrm{K}^{+}$intake reverses BP status. One Potential pathway involves that potassium activate the $\mathrm{Na}^{+}-\mathrm{K}^{+}$pump in the central nervous system and lower BP by neurogenic mechanisms involving central adrenergic as well as dopaminergic pathways (19). Other studies indicated that the vasodilatation induced by potassium results from hyperpolarization of the vascular smooth muscle cells subsequent to potassium stimulation by the ion of the electrogenic $\mathrm{Na}^{+}-\mathrm{K}^{+}$pump and/or by activating the inward rectifying potassium channels $\left(\mathrm{K}_{\mathrm{ir}}\right)$ (9). This hyperpolarization decreases the open probability of-voltage-activated $\mathrm{Ca}^{2+}$ channels, which in turn reduces cytosolic $\mathrm{Ca}^{2+}$ levels and promotes vasodilation (45).

A significant reduction in $\mathrm{HR}$ observed in potassium treated rats, this declining of $\mathrm{HR}$ is almost related to the long treatment of rats with $\mathrm{KCl}$ in this study, and this is consistent with study of (20) reporting that raising serum $\mathrm{K}^{+}$concentrations may improve depolarization in patients with inherited or acquired long QT syndrome.

This study revealed that $\mathrm{KCl}$ supplementation increased NO production in hypertensive rats. Potassium causes the relaxation of arteries through release of several factors from endothelial cells, the most prominent autacoids being $\mathrm{NO}$ and prostacyclin (39). Moreover, High $\mathrm{K}^{+}$intake may enhance NO production in endothelial cells which may be due to prevention of the vascular hypertrophic change with $\mathrm{K}^{+}$supplementation and the another possible mechanism is that $\mathrm{K}^{+}$supplementation inhibits free radical formation and protects endothelial cells from oxidative stress, leading to the increase in the NO production (26).

In the present study, the dietary supplementation of $\mathrm{KCl}$ significantly decreased serum aldosterone level in the hypertensive rats. The mechanisms for inhibition of aldosterone by potassium are probably associated to the indirect interaction between potassium and factors that regulate aldosterone production.

(47) showed that $\mathrm{K}^{+}$ions suppress the secretion of renin and Ang II in hypertensive rats. On the other hand, it has been shown that Ang II activates glomerulosa cells and increases aldosterone production (15), so the decrease in Ang II will decrease the aldosterone production (50) and this may explain the lower range of baseline serum aldosterone concentrations seen in the $\mathrm{KCl}$ treated rats. Moreover, (23) showed that the suppression of hyperaldosteronesim in $2 \mathrm{~K} 1 \mathrm{C}$ with Ang II receptor blockers and ACE inhibitors resulted in significant improvement in hypertension. Also, (67) showed that $\mathrm{K}^{+}$exhibits direct ACE inhibitor activity.

Also, administration of ACE inhibitor to hypertensive patients produced sustained reductions in both plasma aldosterone and urine aldosterone excretion and at the same time caused marked $\mathrm{K}^{+}$retention that's directly related to the fall in aldosterone and changes in both plasma and urine aldosterone suggest that $\mathrm{K}^{+}$reduces secretion of aldosterone by the adrenal cortex (2).

The present study shows that dietary $\mathrm{MgSO}_{4}$ supplementation prevented development of hypertension in hypertensive rats. Magnesium is thought to decrease vascular tone and blood pressure by reducing $\mathrm{Ca}^{2+}$ concentration in smooth muscle cells (64). Inhibition of calcium entry from the extracellular space and calcium release from intracellular stores are believed to be the main mechanisms operating in the vasorelaxant effect of $\mathrm{Mg}^{2+}(27)$.

Supplementation of $\mathrm{MgSO}_{4}$ in diet for 4 weeks produced a significant decrease in HR, suggesting that $\mathrm{MgSO}_{4}$ treatment could be useful in reducing the risk of cardiovascular disease in renovascular and salt loaded hypertension, because HR decreased in these cases. The effects of $\mathrm{Mg}^{2+}$ on HR are related to its ability to influence the movement of other ions across the sarcolemma of the atrial myocytes. The elevation in the $\mathrm{Mg}^{2+}$ concentration could increase the atrial cycle length as a result of its 'interference' with the fine balance between inward $\mathrm{Ca}^{2+}$ and outward $\mathrm{K}^{+}$currents during repolarization of the action potentials in the atrial muscle (24).

Furthermore, supernormal levels of $\mathrm{Mg}^{2+}$ act as type one inward rectifying potassium channels $\left(\mathrm{I}_{\mathrm{K} 1}\right)$ channel blocking agent to plug the open channel in a voltage dependent manner, and decrease the outward $\mathrm{K}^{+}$ current density. Translated into changes in action potential, a prolongation of the final repolarization will occur, accompanied by a slight depolarization of the atrial resting membrane potential and these changes will cause prolonged refractoriness and decreased conduction velocity in the atrial muscle, which in turn could increase the atrial cycle length (25).

Results show that dietary $\mathrm{MgSO}_{4}$ supplementation increased serum NO level induced by $\mathrm{Mg}^{2+}$ in hypertensive rats. This finding indicates that $\mathrm{NO}$ generated by endothelium may potentiate the vasorelaxant effect of magnesium on the vascular smooth muscle cells. Nitric oxide is known to cause relaxation of the vascular smooth muscle through numerous pathways. It activates soluble guanylate cyclase, thus increasing cyclic guanosine monophosphate(cGMP) formation (13).An increase in cGMP causes smooth muscle relaxation by 
various pathways, including inhibition of the calcium influx through the voltage-gated calcium channels and activation of calcium-activated potassium channels, thereby, causing hyperpolarization (11). Therefore, the NOcGMP pathway affects calcium influx and release through numerous cellular mechanisms, and these may be the sites of synergistic interaction between $\mathrm{Mg}^{2+}$ and the NO-cGMP system (33).

Our study showed that dietary intake of $\mathrm{MgSO}_{4}$ caused marked decrease in serum aldosterone concentration. Magnesium has been reported to decrease cytosolic calcium concentration (12). Furthermore, magnesium has been shown to activate membrane $\mathrm{Na}^{+}-\mathrm{K}^{+}$ase in muscle cells, increased $\mathrm{Na}^{+}-\mathrm{K}^{+}$pump activity results in decreased intracellular $\mathrm{Na}^{+}$ion. The $\mathrm{Ca}^{2+}$ ion concentration in the cell would also be decreased as a result of $\mathrm{Na}^{+} / \mathrm{Ca}^{2+}$ exchanges (35). Moreover, (3) reported that $\mathrm{Ca}^{2+}$ is an intracellular messenger of Ang II in adrenal glomerulosa cells and since $\mathrm{Mg}^{2+}$ preferentially inhibits Ang II induced aldosterone production, thus, $\mathrm{Mg}^{2+}$ may inhibit aldosterone production by influencing the intracellular concentration of free $\mathrm{Ca}^{2+}$ in the glomerulosa cells.

In the current results, potassium chloride supplementation reduced MDA level significantly in hypertensive rats. In a study,(36) showed that, dietary $\mathrm{K}^{+}$supplementation counteracted salt and Ang II induced acceleration of vascular injury, possibly, via its antioxidant effect mediated through inactivation of nicotinamide adenine dinucleatid phosphate (NADPH). It has been postulated that an increase in extracellular $\mathrm{K}^{+}$can boost the membrane sodium pump activity, hyperpolarizing the cell membrane and "turning off" NADPH oxidase activation, because membrane depolarization up-regulates the activity of this enzyme complex (29)

supplied with $\mathrm{MgSO}_{4}$. The mechanism by which $\mathrm{Mg}^{2+}$ decreased $\mathrm{MDA}$ is that $\mathrm{Mg}^{2+}$ has important role in the activation of some enzymes involved in the redox reactions (54). Moreover, $\mathrm{Mg}^{2+}$ may directly prevent the production of free radicals or it may facilitate the scavenging of free radicals (16), and Afanas'ev et al., (1995) showed that $\mathrm{Mg}^{2+}$ inhibits reduced NADPH oxidase, an enzyme that produces superoxide radical.

In the present study, concentration of $\mathrm{Na}^{+}$decreased in urine, while, increased in serum in the $2 \mathrm{~K} 1 \mathrm{C}$ rats. These findings correlate with investigations found by (1), confirming that urinary excretion of $\mathrm{Na}^{+}$was higher in normotensive rats than hypertensive rats. Moreover, (28) demonstrated that the mechanism of $\mathrm{Na}^{+}$retention in hypertensive rats is through increased aldosterone activation of the mineralocorticoid hormone receptor in the distal kidney tubules producing $\mathrm{Na}^{+}$and fluid retention and volume expansion, on the other hand, Ang II can increase release of norepinephrine from the adrenals and terminal nerve ending, adrenergic receptor stimulation has been shown to cause increased sodium reabsorption in the renal proximal tubule. The present study shows that $\mathrm{KCl}$ supplementation reduced serum $\mathrm{Na}^{+}$and increased urine excretion $\mathrm{Na}^{+}$concentrations in hypertensiverats. This finding is consistent with, (40), showing that $\mathrm{K}^{+}$has diuretic and natriuretic effects in vivo. Furthermore, (62) concluded that potassium can directly inhibit the release of renin by the juxtaglomerular apparatus, and inhibit proximal tubular $\mathrm{Na}^{+}$reabsorption. Moreover, (59) reported that the release of atrial natriuretic peptide might be increased by $\mathrm{K}^{+}$supplementation, leading to both natriuresis and vasodilation

A significant elevation in serum $\mathrm{K}^{+}$levels was observed in $\mathrm{KCl}$ treated rats, this elevation of $\mathrm{K}^{+}$is almost related to decline in serum aldosterone levels recorded in this study. Studies reported that the increased of serum $\mathrm{K}^{+}$is usually seen when aldosterone concentrations have decreased (30).

Results show that the serum $\mathrm{Cl}^{-}$level was higher in $2 \mathrm{~K} 1 \mathrm{C}$ rats. This result may indicate that overall renal handling of $\mathrm{Na}^{+}, \mathrm{Cl}^{-}$and $\mathrm{K}^{+}$in our hypertensive rats was abnormal. Handling of electrolytes may be modulated by a variety of substances such as aldosterone and the RAAS(36). Furthermore, as it is mentioned in the review of literature, under the effect of aldosterone, $\mathrm{Na}^{+}$ions are reabsorbed, negative ions such as $\mathrm{Cl}^{-}$and bicarbonate $\mathrm{HCO}^{-}$follow the $\mathrm{Na}^{+}$ions back to the blood (56). On the other hand, it was found that increased $\mathrm{Cl}^{-}$transport probably caused by augmented $\mathrm{Na}^{+}-\mathrm{K}^{+}-2 \mathrm{Cl}$ cotransport activity in the thick ascending limb of Henle's loopin the hypertensive rats (4).

In this study, a significant decrease of serum calcium and increase in serum $\mathrm{Mg}^{2+}$ level was observed in hypertensive rats when they were provided with diets supplemented with $\mathrm{MgSO}_{4}$ alone and in combination with KClthe decrease of serum calcium level may be caused by $\mathrm{Mg}^{2+}$ because of its actions on PTH, a hormone which increases calcium reabsorption in the distal parts of the nephron. Therefore, increased plasma $\mathrm{Mg}^{2+}$ would reduce PTH secretion and so reduce distal reabsorption of calcium (42).

Significant increase in serum creatinine was observed in hypertensive rats. This result suggests the role of Ag II in the development of renal injury in this study since it is believed that ROS, Ang II and endothelin are key mediators of kidney damage (63), and also increased serum creatinine and blood urea nitrogen were associated with excessive ROS (32).(31) recorded that renal artery constriction caused local generation of Ang II and up regulation of AT1-receptor density, up-regulation of endothelin system and oxidative stress. Also, renal tubule cell apoptosis has been consistently observed in models of renal injury (55).On the other hand, reduced bioavailability of $\mathrm{NO}$ is considered to be a key mechanism for renal endothelial dysfunction in various experimental models of hypertension and renal damage since, (22) reported that pronounced renal NO-mediated vasodilation is associated with protection against the development of renal damage in several models of renal injury. Also, (58) found that the ability of $\mathrm{K}^{+}$and $\mathrm{Mg}^{2+}$ to NO production may improve renal function. 
In the current study, dietary supplementation of $\mathrm{KCl}$ significantly increased GFR in hypertensive rats. The increase in GFR in hypertensive rats treated with potassium may relate to the increase in NO production. This result is in agreement with the finding of (21) who observed a slight increase in renal blood flow and GFR with the production of local vasodilating agents such as NO. (53) indicated that non selective inhibition of NOS with L-NAME was clearly detrimental to renal function and infact resulted in acute renal failure (decreased GFR accompanied by decreased renal blood flow and tubular dysfunction). Also, it was found that potassium loading enhances the glomerular synthesis of prostaglandins PGE2 and PGI2 (hormones that cause vasodilation and increase renal blood flow and GFR) in normotensive rats (52). Moreover, PGE2 and PGI2 may dampen the renal vasoconstrictor effects of the sympathetic nerves or Ang II, especially their effects to constrict the afferent arterioles and by opposing vasoconstriction of afferent arterioles, the prostaglandins may help prevent excessive reductions in GFR and renal blood follow (18). In conclusion, potassium could improve the renal damage in both models of hypertension by decreasing serum uric acid, urea and increased GFR (which are indications for kidney function) in hypertensive and normotensive rats. Our findings show that oral magnesium supplementation reduced blood pressure in hypertensive rats, while, it could not reduce blood pressure in normotensive rats. Magnesium has an inhibitory action on aldosterone production in hypertensive rats and this suggests that $\mathrm{Mg}^{2+}$ may be involve in physiological regulation of aldosterone production.

\section{REFERENCES}

[1]. Arranz, C., Tomat A., Fellet A., Garcia J. and Balaszczuk A. M., (2003). Renal and vascular nitric oxide system in reduced renal mass saline hypertension. Nephron Physiol. 95 (2): 36-42.

[2]. Atlas, S.A., Case D.B., Sealey J.E., Laragh J.H. and McKinstry D.N., (1979). Interruption of the renin-angiotensin system in hypertensive patients by captopril induces sustained reduction in aldosterone secretion, potassium retention and natruresis. Hypertensio. 1: 274-280.

[3]. Atrashi, K., Matsuoka H., Takagi M. and Sugimoto T., (1989). Magnesium: a possible physiological regulator of aldosterone production. Life science. 44: 1483-1489.

[4]. Aviv, A., Hollenberg N.K., Weder A., (2004). Urinary potassium excretion and sodium sensitivity in blacks. Hypertension. 43: 707-713.

[5]. Badyal, D.K., Lata H. and Dadhich A.P., (2003). Animal models of hypertension and effects of drugs. Indian J. pharmacol. 35: 349-362.

[6]. Barbagallo, M., Dominguez L.J., Galioto A., Ferlisi A., Cani C., Malfa L., Pineo A., Busardo A. and Paolisso G., (2003). Role of magnesium in insulin action, diabetes and cardio-metabolic syndrome. Mol Asp Med. 24: 39-52.

[7]. Braschi, A. and Naismith D.J., (2008). The effect of a dietary supplement of potassium chloride or potassium citrate on blood pressure in predominantly normotensive volunteers. Br J Nutr. 99(6): 1284-1292.

[8]. Cheung, B.M.Y., (2002). Blockade of the renin-angiotensin system. HKMJ 8: 185-191.

[9]. Coca, S.G., Perazella M.A. and. Buller G.K., (2004). The cardiovascular implications of hypokalemia. Kidney Dis. 45: 233-247.

[10]. Cowley, A.W.j., (1992). Long-term control of arterial blood pressure. Physiol. Rev. 72: 231-300.

[11]. Das, R., Kravtsov G.M., Ballard H.J., Kwan C.Y., (1999). L-NAME inhibits Mg2+ -induced rat aortic relaxation in the absence of endothelium. Br J Pharmacol. 128: 493-499.

[12]. Delva, P., (2003). Magnesium and heart failure. Molecular Aspects of Medicine 24: 79-105.

[13]. Denninger, J.W. and Marletta M.A., (1999). Guanylate cyclase and the NO/cGMP signaling pathway. Biochim Biophys Acta., 1411: 334-350.

[14]. Freund, J.E., (1981). Statistics: A first course. 3 edition. Prentic-Hall. INC, New Jersey.

[15]. Gambaryan, S., Butt E., Tas P., Smolenski A., Allolio B. and Walter U., (2006). Regulation of aldosterone production from zona glomerulosa cells by Ang II and cAMP: evidence for PKA-independent activation of CaMK by CaMP. Am J Physiol Endocrinol Metab. 290: 423-433.

[16]. Garcia, L.A., Dejong, S.C., Martin, S. M., Smith, R. S., Buettner, G. R. and Kerber, R.E., (1998). Magnesium reduces free radicals in an in vivo coronary occlusion-reperfusion model. J. Am. Coll. Cardiol. 32: 536-539.

[17]. Germann, W. J. and Stanfield C. L., (2002). Principles of human physiology. Pearson education, Inc.

[18]. Gyuton, A.C and Hall, J.E., (2006). Textbook of medical physiology. Ninth edition. W.B. Saunders Company, Philadelphia.

[19]. Haddy, F.J., Vanhoutte P.M. and Feletou M., (2006). Role of potassium in regulating blood flow and blood pressure. Am J Physiol Regul Integr Comp Physiol. 290: 546-552.

[20]. He, F.J. and MacGregor G., (2007). Beneficial effects of potassium on human health. Physiologia Plantarum. 133: 725-735.

[21]. Henz, S., Maeder T.M., Huber S., Schmid M., Loher M. and Fehr T., (2008). Influence of drug and comorbidity on serum potassium in 15000 consecutive hospital admissions. Nephrol Dial Transplant. 23: 3939-3945.

[22]. Higashi, Y., Sasaki S., Nakagawa K., Matsuura H., Oshima T. and Chayama K., (2002). Endothelial dysfunction and oxidative stress in renovascular hypertension. N Engl J Med. 346: 1954-1962.

[23]. Ibrahim, H.N. and Hostetter T.H., (2000). Role of dietay potassium in the hyperaldosteronism and hypertension of the remnant kidney model. J Am Soc Nephrol. 11: 625-631.

[24]. Ingemansson, M.P., Arlock P. and Olsson S.B., (1998). Effects of magnesium and glucose, insulin, potassium (GIK) solution on the action potential parameters of guinea-pig atrial muscle. Acta Physiol Scand. 164: 173-179. 
[25]. Ingemansson, M.P., Smideberg B. and Olsson S.B., (2000). Intravenous MgSO4 alone and in combination with glucose, insulin and potassium (GIK) prolong the atrial cycle length in chronic atrial fibrillation. Europace. 2: 106114.

[26]. Ishimitsu, T., Tobian L., Sugimoto K. and Everson T., (1996). High potassium diet reduced vascular and plasma lipid peroxides in stroke-prone spontaneously hypertensive rats. Clin Exp Hypertens. 18: 659-673.

[27]. Jee, D., Lee D., Yun S. and Lee C., (2009). Magnesium sulphate attenuates arterial pressure increase during laparoscopic cholecystectomy. Br J. Anaesth. 103: 484-489.

[28]. Karter, C.E. and Biglieri E.G., (2004). The syndrome of low-renin hypertension: separating the wheat from the chaff'. Arq Braq Endocrinol Metab. 48(5): 674-68

[29]. Kido, M., Ando K., Maristela L., Tojo O., Yoshikawa M., Ogita T. and Fujita T., (2007). Protective effect of dietary potassium against vascular injury in salt-sensitive hypertension. Hypertension. 51: 1-8.

[30]. Kim, D.M., Chung J.H., Yoon S.H. and Kim H.L., (2007). Effect of fludrocortisone acetate on reducing serum potassium levels in patients with end-stage renal disease undergoing haemodialysis. Nephrol. Dial. Transplant. 22 (11): 3273-3276.

[31]. Kitiyakara, C., Chabrashvili T., Chen Y., Blau J., Karber A., Aslam S., Welck W.J. and Wilcox C.S., (2004). Salt intake, oxidative stress, and renal expression of NADPH oxidase and superoxide dismutase. J Am Soc Nephrol. 14: $2775-2782$.

[32]. Kumar, V.K., Naidu M., Shifow A. and Ratnakar K.S., (2000). Probucol protects against gentamicin-induced nephrotoxicity in rats. Indian J Pharmacol. 32: 108-113.

[33]. Longo, M., Jain V., Vedernikov Y.P., Facchinetti F., Saade G. and Garfield R.E., (2001). Endothelium dependence and gestational regulation of inhibition of vascular tone by magnesium sulfate in rat aorta. Am J Obstet Gynecol. 184(5): 971-978.

[34]. Maldonaldo, M.M., (1991). Pathophysology of renovascular hypertension. Hypertension. 17: 707-719.

[35]. Matsuoka, H., (2005). Aldosterone and magnesium. Clin Calcium. 15(2): 187-191.

[36]. McCabe, R.D., Bakarich M.A., Srivastava K. and Young D.B., (1994). Potassium inhibits free radical formation. Hypertension. 24: 77-82.

[37]. Melaragno, G.M. and Fink G.D., (1996). Change in Pressor Responsiveness to Angiotensin II as a Determinant of Blood Pressure After Unclipping in Two-Kidney, One Clip Hypertensive Rats.Hypertension.28:656-662.

[38]. Mitchell, K. D. and L. G. Navar., (1995). Intrarenal actions of angiotensin II in the pathogenesis of experimental hypertension in: Hypertension: Pathophysiology, Diagnosis, and Management, edited by J. H. Laragh and B. M. Brenner. New York: Raven, 1437-1450.

[39]. Moncada, T.F., Palmer R.M.J. and Higger E.A., (1991). Nitric oxide: physiology, pathophysiology, and pharmacology. Pharmacol Rev. 43: 109 -142.

[40]. Morris, R.C., Schmidlin O., Frassetto L.A. and Sebastian A., (2006). Relationship and interaction between sodium and potassium. Journal of the American College of Nutrition. 25(3): 262-270.

[41]. Navar, L.G., Zou, L., Thun, A.V., Wang C.T., Imig, J.D. and Mitchell, K.D., (1998). Unraveling the mystery of goldblatt hypertension. News physiol Sci. 13: 170-176.

[42]. Navarro, J.F., Mora C., Garcia J., (2000). Serum magnesium and parathyroid hormone levels in dialysis patients. Kidney Int. 57(6): 2654-2656.

[43]. Palm,F.,Connors S.G.,Mendosa, M., Welch W.L. and Wilcox C.S., (2007). Angiotensin II type receptors and nitric oxide sustain oxygenation in the clipped kdney of early Goldblatt hypertensive rats. Hypertension.51:345-351.

[44]. Palm,F.,Onozato M.,Welch W.J. and Wilcox C.S.,(2009). Blood pressure,blood flow, and oxygenation in the clipped kidney of chronic 2-kidney,1-clip rats: effects of tempol and angiotensin blockade.Hypertension 55:298304.

[45]. Pang, L.I. and Rusch N.J., (2010). High-conductance, Ca2+-activated K+ channels: altered expression profiles in aging and cardiovascular disease. Mol Interv. 10: 252-258.

[46]. Patki, P.S., Singh J., Gokhale S.V., Bulakh P.M. and Bhushan P., (1990). Efficacy of potassium and magnesium in essential hypertension: a double blind, placebo controlled, crossover study. Br Med J. 301: 521-523.

[47]. Pellegrin, M., Alonso F., Aubert J., Bouzourene K., Baraunersreuther V., Mach F., Haefliger J., Hayoz D., Berthelot A., Nussberger J., Laurant P. and Mazzolai L., (2009). Swimming prevents vulnerable atherosclerotic plaque development in hypertensive 2-kidney, 1-clip mice by modulating angiotensin II type 1 receptor expression independently from hemodynamic changes. Hypertension. 53: 782-789.

[48]. Pellegrin, M., Alonso F., Aubert J., Bouzourene K., Baraunersreuther V., Mach F., Haefliger J., Hayoz D., Berthelot A., Nussberger J., Laurant P. and Mazzolai L., (2009). Swimming prevents vulnerable atherosclerotic plaque development in hypertensive 2-kidney, 1-clip mice by modulating angiotensin II type 1 receptor expression independently from hemodynamic changes. Hypertension. 53: 782-789.

[49]. Pinet, F., Poirier F., Fuchs S., Tharauax P., Caron M., Corvol P., Michel J. and Caron R., (2004). Troponin T as a marker of differentiation revealed by proteomic analysis in renal arterioles. The FASEB journal. 18(3):585-586.

[50]. Pitt,B.,(1995). Escape of aldosterone production in patients with left ventricular dysfunction treated with an angiotensin converting enzyme inhibitor: implications for therapy. Cardiovascular Drugs and Therapy. 9:145-149.

[51]. Prieto-Carrasquero, P.C., Botros F.T., Pagan J., Kobori H., Seth D.M., Casarini D.E. and Navar G.N., (2008).Collecting duct renin is upregulated in both kidneys of 2-Kidney, 1-Clip Goldblatt hypertensive rats. Hypertension. 51(6): 1590-1596.

[52]. Rathaus, M., Pomeranz E., Podjarny E. and Bernheim J., (1991). Potassium load prevents the decrease of GFR induced by captopril in sodium-dependent rats. The American physiological society. 258(3):670-674. 
[53]. Rubin, I., Cohen ., Hassell A., Marzouk K., Marinic C, Liu S.F, and Steven M., (2001). Renal effects of nitric oxide in endotoxemia. Am J Respir Crit Care Med. 164: 1890-1895.

[54]. Sahin, N., Onderci M., Sahin K., Cikim G. and Kucuk O., (2005). Magnesium proteinate is more protective than magnesium oxide in heat-stressed. Quail. J. Nutr. 135: 1732-1737.

[55]. Salahudeen, A.K., Joshi M. and Jenkins J.K., (2001). Apoptosis versus necrosis during cold storage and rewarming of human renal proximal tubular cells. Transplantation. 72: 798-804.

[56]. Scanlon, V.C. and Sanders T., (2007). Essentionals of anatomy and physiology. Fifth edition. F.A. Davis company. Philadelphia

[57]. Schroeder,E.B.,Laio D.,ChamblessL.E.,Prineas R.J., Evan G.W.and Heiss G., (2003).Hypertension,blood pressure, and heart rate variability:the atherosclerosis risk in communities (ARIC) study.Hypertension.42:1106-1111.

[58]. Sharikabad, M.N., Ostbye K.M., Lyberg T. and Brors O., (2001). Effect of extracellular Mg2+ on ROS and Ca2+ accumulation during reoxygenation of rat cardiomyocytes. Am J Physiol Heart Circ Physiol. 280(1): 344-353.

[59]. Smith, S.S., Klotman P.E. and Svetky L.P., (2002). Potassium chloride lowers blood pressure and causes natriuresis in older patients with hypertension. J. Am. Soc. Nephrol. 2: 1302-1309.

[60]. Sontia, B., Touyz R.M., (2007). Role of magnesium in hypertension. Arch Biochem Biophys. 458: 33-39.

[61]. Sugiyama, T., Xi D., Graham-Maar R.C., Inoue K., Kobayashi K. and Stettler N., (2007). Dietary and Lifestyle Factors Associated with Blood Pressure among U.S. Adolescents. Journal of Adolescent Health. 40: 166-172.

[62]. Suzuki, H., Kondo K. and Saruta T., (1981). Effect of potassium chloride on the blood pressure in two-kidney, one clip Goldblatt hypertensive rats. Hypertension.3: 566-573.

[63]. Tanaka, J. and Yuda Y., (1993). Role of lipid peroxidation in gastric mucosal lesions induced by ischemiareperfusion in the pylorus-ligated rat. Biol. Pharm. Bull. 16: 29-32.

[64]. Touyz, R.M., Laurant P. and Ernesto L.S., (1998). Effect of magnesium on calcium responses to vasopressin in vascular smooth muscle cells of spontaneously hypertensive rats. JPET. 284: 998-1005.

[65]. Varley, H., Gowenlock A.H. and Bell M., (1980). Practical clinical biochemistry, Volume 1, General tooics and commoner tests. Fifth eddition, William Heinemann Medical books, LTD, (London).

[66]. Yazdanpanah, M., Aulchenko Y.S., Hofman A., Janssen J.A.M., Sayed-Tabatabaei F.A., Van Schaik R.H.N., Klungel O.H., Stricker B.H.C.H., Pols H.A.P., Witteman J.C.M., Lamberts S.W.J., Oostra B.A. and van Duijn C.M.,(2007). Effects of the renin-angiotensin system genes and salt sensitivity genes on blood pressure and atherosclerosis in the total population and patients with type 2 diabetes. Diabetes. 56(7): 1905-1912.

[67]. Yoshida, J., Yamamoto K., Mano T., Sakata Y., Nishikawa N., Nishio M., Ohtani T., Miwa T., Hori M. and Matsuyama T., (2004). AT1 receptor blocker added to ACE inhibitor provides benefits at advanced stage of hypertensive diastolic heart failure. Hypertension. 43: 686-691.

Table (1): Effects of potassium, magnesium and their combination on SBP, HR, serum NO, serum aldosterone level and MDA in $2 \mathrm{~K} 1 \mathrm{C}$ hypertensive rats.

\begin{tabular}{|c|c|c|c|c|c|}
\hline $\begin{array}{c}\text { Parameters } \\
\text { Treatments }\end{array}$ & SBP(mmHg) & HR(beats/min) & Serum $\mathrm{NO}(\boldsymbol{\mu m o l} / \mathbf{L})$ & $\begin{array}{c}\text { Serum } \\
\text { aldosterone }((\mathbf{p g} / \mathbf{m l})\end{array}$ & $\begin{array}{c}\text { Serum } \\
\operatorname{MDA}((\mu \mathrm{mol} / \mathrm{L})\end{array}$ \\
\hline Control & $111.5 \pm 0.56^{\mathrm{ab}}$ & $341.1 \pm 6.7^{a b}$ & $8.16 \pm 0.04^{\mathrm{a}}$ & $12.96 \pm 1.05^{\mathrm{a}}$ & $2.09 \pm 0.04^{\mathrm{a}}$ \\
\hline Sham & $113.8 \pm 0.8^{b}$ & $400.0 \pm 5.3^{b}$ & $8.29 \pm 0.04^{\mathrm{a}}$ & $11.14 \pm 0.4^{\mathrm{a}}$ & $2.19 \pm 0.10^{\mathrm{a}}$ \\
\hline $2 \mathrm{~K} 1 \mathrm{C}$ & $149.1 \pm 3.52^{d}$ & $471.1 \pm 4.9^{\mathrm{c}}$ & $8.22 \pm 0.11^{\mathrm{a}}$ & $59.6 \pm 10.0^{b}$ & $5.57 \pm 0.23^{c}$ \\
\hline $\begin{array}{c}2 \mathrm{~K} 1 \mathrm{C}+\mathrm{KCl} \\
(80 \mathrm{gms} / \mathrm{kg} \text { diet })\end{array}$ & $115.5 \pm 0.36^{b c}$ & $397.6 \pm 3.4^{b}$ & $9.27 \pm 0.13^{b}$ & $7.8 \pm 2.0^{\mathrm{a}}$ & $3.11 \pm 0.06^{b}$ \\
\hline $\begin{array}{l}2 \mathrm{~K} 1 \mathrm{C}+\mathrm{MgSO}_{4} \\
\text { (80gms/kg diet) }\end{array}$ & $110.5 \pm 0.42^{\mathrm{a}}$ & $406.8 \pm 1.7^{b}$ & $9.43 \pm 0.28^{b}$ & $14.52 \pm 1.18^{\mathrm{a}}$ & $2.50 \pm 0.1^{\mathrm{a}}$ \\
\hline $\begin{array}{c}2 \mathrm{~K} 1 \mathrm{C}+\mathrm{KCl}+ \\
\mathrm{MgSO}_{4}(160 \mathrm{gms} / \mathrm{kg} \\
\text { diet })\end{array}$ & $107.30 .42^{a}$ & $395.1 \pm 4.1^{b}$ & $9.00 \pm 0.23^{b}$ & $14.56 \pm 2.13^{\mathrm{a}}$ & $2.42 \pm 0.15^{\mathrm{a}}$ \\
\hline
\end{tabular}

The data presented as mean \pm SE measured after 4 weeks of the treatments in all groups ( Control Sham operated surgery rats, Two kidney-one clip (2K1C) hypertensive rats, $2 \mathrm{~K} 1 \mathrm{C}+$ Potassium chloride , $\mathrm{KCl}$, $2 \mathrm{~K} 1 \mathrm{C}+$ Magnesium sulphate ,MgSO $4,2 \mathrm{~K} 1 \mathrm{C}+\mathrm{KCl}+\mathrm{MgSO} 4$.

The same letters mean non significant differences while the different letters mean significant differences $=\mathrm{p}<0.05 \quad * *=\mathrm{p}<0.01$ 
Effects of potassium and magnesium on some hemodynamic and renal function related...

Table (2): Effects of potassium, magnesium and their combination on serum $\mathrm{Na}^{+}, \mathrm{K}^{+}, \mathrm{Cl}^{-}, \mathrm{Mg}^{2+} \mathrm{Ca}^{2+}$ and urine $\mathrm{Na}^{+}$concentration in $2 \mathrm{~K} 1 \mathrm{C}$ hypertensive rats.

\begin{tabular}{|c|c|c|c|c|c|c|}
\hline Parameters & $\begin{array}{c}\text { Serum } \\
\mathrm{Na}^{+}(\mathbf{m m o l} /)\end{array}$ & $\begin{array}{c}\text { Serum } \\
\mathbf{K}^{+} \\
(\mathbf{m m o l} / \mathbf{L})\end{array}$ & $\begin{array}{c}\text { Serum } \\
\mathrm{Cl}^{-} \\
(\mathbf{m m o l} / \mathbf{L})\end{array}$ & $\begin{array}{c}\text { Serum } \\
\mathbf{M g}^{2+} \\
(\mathbf{m g} / \mathbf{d L})\end{array}$ & $\begin{array}{c}\text { Serum } \\
\mathrm{Ca}^{2+}(\mathrm{mg} / \mathrm{dL})\end{array}$ & $\begin{array}{c}\text { Urine } \\
\mathrm{Na}^{+}(\mathrm{mmol} / \mathrm{L}) \\
*\end{array}$ \\
\hline Control & $127.8 \pm 1.14^{\mathrm{a}}$ & $3.87 \pm 0.7^{\mathrm{a}}$ & $104.6 \pm 0.7^{\mathrm{a}}$ & $1.30 \pm 0.18^{\mathrm{a}}$ & $9.37 \pm 0.07$ & $199.71 \pm 0.99^{a}$ \\
\hline Sham & $128.00 .58^{\mathrm{a}}$ & $4.13 \pm 0.20$ & $106.2 \pm 0.7^{\mathrm{ab}}$ & $1.3 \pm 0.14^{\mathrm{a}}$ & $9.43 \pm 0.13^{b}$ & $201.5 \pm 1.23^{\mathrm{a}}$ \\
\hline $2 \mathrm{~K} 1 \mathrm{C}$ & $129.331 .7^{\mathrm{c}}$ & $3.82 \pm 0.15$ & $115.4 \pm 0.5^{\mathrm{c}}$ & $1.38 \pm 0.14^{\mathrm{a}}$ & $9.39 \pm 0.08^{b}$ & $206.6 \pm 1.33^{b}$ \\
\hline $\begin{array}{c}2 \mathrm{~K} 1 \mathrm{C}+\mathrm{KCl} \\
(80 \mathrm{gms} / \mathrm{kg} \text { diet })\end{array}$ & $123.05 \pm 1.7^{\mathrm{a}}$ & $5.11 \pm 0.10$ & $116.4 \pm 0.6^{\mathrm{c}}$ & $1.48 \pm 0.24$ & $9.42 \pm 0.05^{b}$ & $212.0 \pm 0.81^{\mathrm{c}}$ \\
\hline $\begin{array}{l}2 \mathrm{~K} 1 \mathrm{C}+\mathrm{MgSO}_{4} \\
\text { (80gms } / \mathrm{kg} \text { diet) }\end{array}$ & $131.0 \pm 1.34^{\mathrm{c}}$ & $3.70 \pm 0.15$ & $108.6 \pm 0.21^{b}$ & $2.11 \pm 0.06^{b}$ & $7.07 \pm 0.17^{\mathrm{a}}$ & $203.8 \pm 0.83^{b}$ \\
\hline $\begin{array}{c}2 \mathrm{~K} 1 \mathrm{C}+\mathrm{KCl}+\mathrm{MgSO}_{4}( \\
160 \mathrm{gms} / \mathrm{kg} \text { diet })\end{array}$ & $124.6 \pm 1.2^{b}$ & $5.30 \pm 0.18$ & $109.6 \pm 0.7^{b}$ & $2.16 \pm 0.06$ & $7.16 \pm 0.19$ & $206.3 \pm 1.97^{b}$ \\
\hline
\end{tabular}

The data presented as mean $\pm \mathrm{SE}$ measured after 4 weeks of the treatments in all groups ( Control , Sham operated surgery rats, Two kidney-one clip (2K1C) hypertensive rats, 2K1C + Potassium chloride , KCl , $2 \mathrm{~K} 1 \mathrm{C}+$ Magnesium sulphate , MgSO4 , 2K1C +KCl+MgSO4 .The same letters mean non significant differences while the different letters mean significant differences $*=\mathrm{p}<0.05 \quad * *=\mathrm{p}<0.01$ 